\title{
Comparison of three shredders response to acute stress induced by eucalyptus leaf leachates and copper: single and combined exposure at two distinct temperatures
}

\author{
M. Gama ${ }^{1,2 *}$, L. Guilhermino ${ }^{2,3}$ and C. Canhoto ${ }^{1}$ \\ 1 IMAR \& Department of Life Sciences, University of Coimbra, 3004-517 Coimbra, Portugal \\ 2 CIIMAR - Interdisciplinary Centre of Marine and Environmental Research, Laboratory of Ecotoxicology and Ecology, \\ University of Porto, Rua dos Bragas, 289, 4050-123 Porto, Portugal \\ 3 ICBAS - Institute of Biomedical Sciences of Abel Salazar, Department of Populations Studies, Laboratory of Ecotoxicology, \\ University of Porto, Rua Jorge Viterbo Ferreira, 228, 4050-313 Porto, Portugal
}

Received 15 May 2013; Accepted 8 January 2014

\begin{abstract}
The objectives of this study were to compare the sensitivity of three freshwater macroinvertebrate shredder species (Atyaephyra desmarestii, Echinogammarus meridionalis and Schizopelex festiva) to acute stress induced by eucalyptus leaf extracts and copper, independently and in mixtures, and the ability of temperature to influence the chemicals' toxicity. Laboratory bioassays based on mortality with single substances and mixtures were carried out with the three species at 10 and $20^{\circ} \mathrm{C}$. After $96 \mathrm{~h}$ of exposure, S. festiva, A. desmarestii and $E$. meridionalis were found to have differences of sensitivity to copper, eucalyptus leaf extracts and their mixtures, with S. festiva being the least sensitive species at both 10 and $20^{\circ} \mathrm{C}$. The relative sensitivity of $A$. desmarestii and E. meridionalis to chemical exposure seems to be chemical and temperature dependent. Overall, these findings suggest that chemical stress may modulate the biodiversity of stream shredders communities due to differential sensitivity of individual species to environmental contaminants, and that temperature may influence the process. Thus, more knowledge on the combined effects of multi-stressors is needed, particularly on temperature and chemicals' interactions and on the molecular mechanisms underlying the responses observed at individual level.
\end{abstract}

Key words: Chemical acute toxicity / combined effects of stressors / Atyaephyra desmarestii / Echinogammarus meridionalis / Schizopelex festiva

\section{Introduction}

Small forested streams depend on their riparian areas as source of energy and nutrients (Vannote et al., 1980; Richardson and Danehy, 2007). Their strong interactions with the catchment and their relative low water volume make them particularly vulnerable to changes caused by natural factors and/or anthropogenic activities (Malmqvist and Rundle, 2002; Ormerod et al., 2010; Woodward et al., 2010). Headwater streams may constitute up to $80 \%$ of the total length of the fluvial net (Allan and Castillo, 2007). These heterotrophic systems play a pivotal role as hot spots of biodiversity and are key organic matter suppliers to higher-order streams (Perkins et al., 2010). Thus, efforts should be devoted to the preservation of their good ecological status.

\footnotetext{
*Corresponding author: ana.gama@ci.uc.pt
}

Detritus processing is a key process for the stream heterotrophic production that is primarily undertaken by fungi, namely aquatic hyphomycetes, and shredders (Cummins, 1973; Gessner et al., 2010), a functional feeding group of detritivorous invertebrates. The abundance and richness of these shredder communities mainly depend on water physicochemical characteristics and is closely linked with the type, amount, spatial and temporal distribution of leaves in the watercourse (Gessner et al., 2010). The importance of this group, as a link between detritus and higher trophic levels, and the distinct sensitivities of macrobenthos to environmental factors make them important tools to assess the effects of environmental stressors on stream ecosystems (Brix et al., 2011; Liess and Beketov, 2011; Peters et al., 2011). Alterations in these macroinvertebrate communities potentially resulting from the influence of single or multiple stressors, may have consequences at higher levels of biological organization 
and ecosystem functioning (Sanpéra-Calbet et al., 2009; McMahon et al., 2012).

Forestry practices constitute one of the main threats to streams (Lecerf and Richardson, 2010). Among these, exotic eucalyptus afforestations are now one of the main causes of stream's impairment in several regions (e.g. Santos, 1997; Molinero and Pozo, 2004; Kominoski et al., 2013). Eucalyptus (namely Eucalyptus globulus) monocultures are frequently associated with altered flow regimes, modified food webs and distinct dynamics of organic matter, where shredder's role as leaf processors has been reduced (Graça et al., 2002; Larrañaga et al., 2009). This has been related to low eucalyptus leaf litter quality and direct toxicity (Canhoto \& Graça, 1999). Whether these effects are generalized across the shredders guild or modulated by temperature is still not known but particularly important in an era where air and water thermal conditions are changing (Morrill et al., 2005; IPCC, 2007).

In addition to natural toxins, other environmental contaminants may be present in stream's water and sediments. Among these, ubiquitous contaminants such as metals (e.g. copper) are of special interest because they are introduced at considerable amounts in aquatic ecosystems as result of several anthropogenic activities (e.g. different industries, mining activities, agriculture, veterinary and human medicine) and natural processes (e.g. volcanic eruptions). Metals have been found to induce adverse effects on shredders ecology as a result of long-term exposure to low environmental contamination levels (Farag et al., 1998; Leslie et al., 1999; Forrow and Maltby, 2000; MacedoSousa et al., 2007; Faria et al., 2007, 2008; Hogsden and Harding, 2012), or to punctual or pulses exposure to high levels (Macedo-Sousa et al., 2008; Dédourge-Géffard et al., 2009). In the last years, some studies showed that the presence of metals in streams may affect leaf conditioning processes and consequently shredders performance (Batista et al., 2012; Pradhan et al., 2012). However, a lack of knowledge on the combined effects of leaf toxins and metal contamination to shredders still exists.

Temperature has a major influence in biological and ecological processes: it may be a stressor by itself (Ferreira et al., 2010; McFeeters and Frost, 2011; Wojewodzic et al., 2011), it may modify the toxicity of chemicals (Prato et al., 2009; Lapointe et al., 2011; Vieira and Guilhermino, 2012), and may change abiotic conditions (e.g. water eutrophication and oxygen depletion) (Woodward et al., 2010). Furthermore, warmer temperatures are usually coupled with low flow events (Malmqvist and Rundle, 2002; Woodward et al., 2010; Canhoto et al., 2013) that favour the increased concentration of chemical contaminants in the water (Chatzinikolaou, 2006). Considering the expected warming scenarios resulting of global climate changes (IPCC, 2007), and the predictable increase of chemicals use by a growing human population (Dudgeon et al., 2006), it is most important to investigate the combined effects of chemical and thermal stress on the protagonists of key stream ecosystem-level processes (i.e. leaf litter decomposition) such as shredders.
The objective of this study was to compare the sensitivity of three shredder species [Atyaephyra desmarestii Millet (1981), Echinogammarus meridionalis Pinkster (1973) and Schizopelex festiva Rambur (1842)] to acute stress induced by eucalyptus leaf leachates and a copper, independently and in mixture. Considering the ability of temperature to influence chemicals' toxicity (Boeckman and Bidwell, 2006; Prato et al., 2009), tests were performed at 10 and $20^{\circ} \mathrm{C}$. These are common temperatures in colder and warmer seasons, respectively, in the streams where the invertebrates were collected (Canhoto and Laranjeira, 2007; Ferreira et al., 2010). A. desmarestii, E. meridionalis and $S$. festiva were selected for this study because they play a key role in leaves decomposition in low-order streams where they occur, are abundant and easily maintained in the laboratory. Furthermore, A. desmarestii and E. meridionalis have been widely used as model species in ecology and ecotoxicology (Pantani et al., 1997; Gerhardt et al., 2004; Pestana et al., 2007; Macedo-Sousa et al., 2007, 2008).

\section{Material and methods}

\section{Collection and acclimatization of invertebrates}

Organisms were collected in the wild (A. desmarestii: $40^{\circ} 10^{\prime} \mathrm{N}, \quad 8^{\circ} 18^{\prime} \mathrm{W} ; \quad$ E. meridonalis: $39^{\circ} 59^{\prime} \mathrm{N}, \quad 8^{\circ} 34^{\prime} \mathrm{W}$; S. festiva: $40^{\circ} 32^{\prime} \mathrm{N}, 8^{\circ} 09^{\prime} \mathrm{W}$ ) from January 2010 to February 2011, including those used in preliminary assays. Individuals were brought to the laboratory in coolers filled with stream water. In the laboratory, they were maintained in $5 \mathrm{~L}$ aquaria filled with aerated ASTM hard water (ASTM, 1980), with a layer of $(10 \mathrm{~cm})$ sterile sediment, under a $12 \mathrm{~h}$ light (L): $12 \mathrm{~h}$ dark (D) photoperiod. Specimens were fed ad libitum for 1 week prior to the start of the test, with conditioned alder leaves (as described below), with medium renewal every other day until the beginning of the experiments. During this period, half of the invertebrates from each species were maintained at $10 \pm 1{ }^{\circ} \mathrm{C}$ and the other half at $20 \pm 1{ }^{\circ} \mathrm{C}$ according to their further use in bioassays. Alder leaves were collected from the same stands of trees in autumn 2009, just after abscission, and were air-dried and stored until needed. Leaves were weighed in batches of 4.5-5 g, moistened, enclosed in coarse mesh bags (10 $\mathrm{mm}$ mesh size) and colonized, for 3 weeks, in Ribeira de S. João, Portugal $\left(40^{\circ} 11^{\prime} \mathrm{N} ; 8^{\circ} 25^{\prime} \mathrm{W}\right)$.

\section{Bioassays with eucalyptus leachates}

An original eucalyptus leaf leachate, hereafter indicated as stock-eucalypt leachates (EL), was prepared from senescent eucalyptus leaves (E. globulus) collected just after abscission between September and October 2009 in Pinhal de Marrocos, Coimbra, Portugal $\left(40^{\circ} 11^{\prime} \mathrm{N}\right.$; $\left.8^{\circ} 24^{\prime} \mathrm{W}\right)$. Leaves were transported to the laboratory, air dried in paper boxes at room temperature in the dark, and 
Table 1. Physico-chemical characteristics of the original eucalyptus leachate solution (stock-EL). For each parameter, the values are the means of three determinations in the stockEL with corresponding standard deviation.

\begin{tabular}{lc}
\hline Parameters & Average $( \pm \mathrm{SD})$ \\
\hline $\mathrm{pH}$ & $3.90(0.115)$ \\
Conductivity $\left(\mu \mathrm{S} . \mathrm{cm}^{-1}\right)$ & $1116(54.354)$ \\
Tannic acid equivalents $\left(\mathrm{mg} . \mathrm{L}^{-1}\right)$ & $465(41.8)$ \\
Oxygen $\left(\mathrm{mg} . \mathrm{L}^{-1}\right)$ & $1.70(0.231)$ \\
DOC $\left(\mu \mathrm{g} . \mathrm{L}^{-1}\right)$ & $2.53(0.055)$ \\
\hline
\end{tabular}

stored until needed. Leaf leaching was obtained from $28 \mathrm{~g} . \mathrm{L}^{-1}$ of dried eucalyptus leaves immersed in the ASTM hard water (ASTM, 1980) (alkalinity $110-120 \mathrm{mg} . \mathrm{L}^{-1}$ as $\mathrm{CaCO}_{3}$ and hardness $160-180 \mathrm{mg} . \mathrm{L}^{-1}$ as $\mathrm{CaCO}_{3}$ ), here after indicated as ASTM, for 7 days, under continuous moderate aeration $\left(15^{\circ} \mathrm{C} \pm 1\right.$; photoperiod $12 \mathrm{~h}$ light: $12 \mathrm{~h}$ dark) according to Canhoto and Laranjeira (2007). The leachate was decanted and stored at $4{ }^{\circ} \mathrm{C}$ until further use. Before the experiments, the stock-EL was analysed for total polyphenols (Graça et al., 2005), pH (JENWAY 3310, Essex, UK), conductivity (WTW LF 330, Weilheim, Germany), dissolved organic carbon (DOC) (Elementar Analysensysteme Gmbh LiquiTOC, Hanau, Germany) and dissolved oxygen (D.O.) (WTW ProfiLine Oxi 3210, Weilheim, Germany). The characterization of the stock-EL is indicated in Table 1.

From the stock-EL, dilutions $(1: 2(\mathrm{v} / \mathrm{v}))$ in ASTM were prepared to obtain the following test concentrations: $100 \%$ (no dilution), 50, 25, 12.5, 6.25, 3.13 and $1.56 \%$. These solutions were used as different treatments in the bioassays with EL and contained the following concentrations of tannic acid: 465, 232.5, 116.3, 58.1, 29.1, 14.5 and $7.3 \mathrm{mg} . \mathrm{L}^{-1}$. Hereafter, the different treatments will be indicated in relation to their tannic acid concentrations. An additional treatment (ASTM only) was used as control. Because of a low response of S. festiva to the lowest concentrations tested in the first bioassays, two other bioassays were carried out with this species with the following concentrations of tannic acid: 349, 412 and $465 \mathrm{mg} . \mathrm{L}^{-1}$ (corresponding to 75,89 and $100 \%$ of the stock-EL) at $10^{\circ} \mathrm{C} ; 279,325$ and $434 \mathrm{mg} . \mathrm{L}^{-1}$ (corresponding to 60,70 and $93 \%$ of the stock-EL) at $20^{\circ} \mathrm{C}$. The pH of test solutions, measured at the beginning of the bioassays is indicated in supplementary material (Appendix 1). The bioassays were carried out under laboratory conditions (12:12-h light/dark photoperiod; $10 \pm 1{ }^{\circ} \mathrm{C}$ or $20 \pm 1{ }^{\circ} \mathrm{C}$ ). A total of 160 organisms per species $(n=80$ for each temperature) were used, with the following ranges of dry weight (mean dry weight (d.w.) \pm standard deviation): $2.667 \pm 0.024 \mathrm{mg}$ for $A$. desmarestii, $1.109 \pm 0.008 \mathrm{mg}$ for E. meridionalis and $0.0159 \pm 0.0002 \mathrm{mg}$ for $S$. festiva. In each bioassay, ten individuals were randomly distributed per treatment in eight different treatments corresponding to seven EL treatments and one control (ASTM). Organisms were individually exposed in plastic beakers filled with $200 \mathrm{ml}$ of the test solution with continuous aeration. Feeding was stopped $24 \mathrm{~h}$ before the starting of the assays and no food was provided during the exposure period $(96 \mathrm{~h})$. Effect criterion was mortality, recognized by the immobility after stimulation by a gentle touch with a plastic pipette or when found outside the case for S. festiva. Water temperature, conductivity, pH, D.O. and mortality were monitored at beginning of the bioassays and at each $24 \mathrm{~h}$ intervals.

\section{Bioassays with copper}

Copper 96 h-bioassays were carried out with single species at both temperatures under laboratorial conditions similar to those described for EL bioassays (12:12-h light/ dark photoperiod; $10 \pm 1$ or $20 \pm 1{ }^{\circ} \mathrm{C}$ ). For each bioassay, a stock solution of copper sulphate pentahydrate (CAS no. 7758-99-8, $\geq 98 \%$ purity, purchased from Merck KGaA, Darmstadt, Germany) was prepared in ultra-pure water (conductivity $<5 \mu \mathrm{S} . \mathrm{cm}^{-1}$; Seralpur PRO $90 \mathrm{CN}$, Seral, Ransbach-Baumbach, Germany). The concentration of the stock solution was $25.5 \mathrm{mg} . \mathrm{L}^{-1}$ ( $\mathrm{Cu}$ concentration). Test solutions were obtained by serial dilution of the stock solution in ASTM (ASTM, 1980). The following $\mathrm{Cu}$ concentrations were tested (selection based on preliminary bioassays): $3.26,1.63,0.81,0.41,0.20,0.10,0.05$ and $0.03 \mathrm{mg} . \mathrm{L}^{-1}$ for $A$. desmarestii at both temperatures; 0.81 , $0.41,0.20,0.10,0.05$ and $0.03 \mathrm{mg} . \mathrm{L}^{-1}$ for E. meridionalis at $10^{\circ} \mathrm{C}$ and $0.41,0.20,0.10,0.05,0.03,0.01$ and $0.006 \mathrm{mg} . \mathrm{L}^{-1}$ for E. meridionalis at $20^{\circ} \mathrm{C}$; and 8.14, 4.07, 2.04, $1.02,0.51$ and $0.25 \mathrm{mg} . \mathrm{L}^{-1} \mathrm{Cu}$ for S. festiva at both temperatures. The $\mathrm{pH}$ of test solutions, measured at the beginning of the bioassays is indicated in the supplementary material (Appendix 1).

To assess the lethal toxicity of copper, 180 specimens of $A$. desmarestii ( $n=90$ for each temperature), and 160 E. meridionalis and S. festiva were used $(n=80$ for each temperature) with the following ranges of dry weight (mean d.w. $\pm \mathrm{SD}$ ): $2.90 \mathrm{mg} \pm 0.01$ for $A$. desmarestii, $1.12 \mathrm{mg} \pm 0.002$, for $E$. meridionalis and 0.017 $\mathrm{mg} \pm 0.0002$ for $S$. festiva. Ten individuals were randomly distributed per treatment as described in the section 'Bioassays with eucalyptus leachates'.

\section{Combined effects of eucalyptus leachates and copper, and temperature effects}

The experimental design for mixture bioassays, carried out at 10 and $20^{\circ} \mathrm{C}$ with the three species, was based on the $\mathrm{LC}_{10}, \mathrm{LC}_{20}$ and $\mathrm{LC}_{50}$ obtained in the bioassays with single substances (Table 2), except in the case of $S$. festiva. For this species, the concentration of tannic acid in the $100 \%$ eucalyptus leachates treatment (465 mg.L $\left.{ }^{-1}\right)$ was tested, because the $\mathrm{LC}_{50}$ of tannic acid calculated from data of the bioassay with EL alone was higher than the tannic acid concentration present in the EL stock solution (Table 1). Briefly, for each mixture bioassay and for each temperature, four treatments were considered: control (ASTM only), copper $\mathrm{LC}_{10}+$ eucalyptus leachates $\mathrm{LC}_{10}$ 


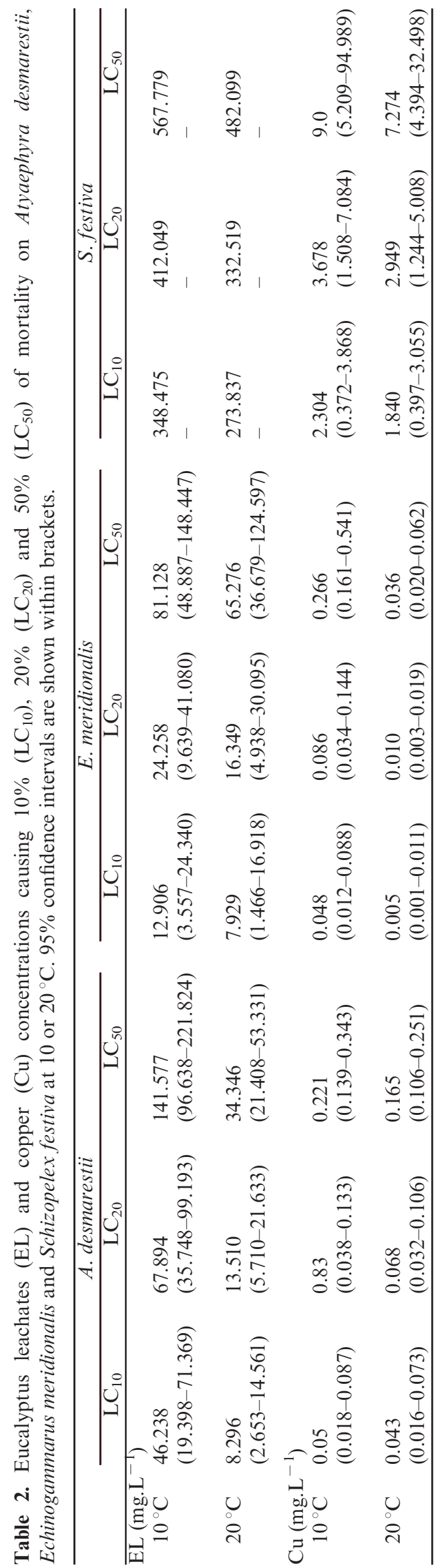

$\left(\mathrm{Cu}-\mathrm{LC}_{10}+\mathrm{EL} \mathrm{LC}_{10}\right) ;$ copper $\mathrm{LC}_{20}+$ eucalyptus leachates $\mathrm{LC}_{20}\left(\mathrm{Cu}-\mathrm{LC}_{20}+\mathrm{EL}-\mathrm{LC}_{20}\right)$; and copper $\mathrm{LC}_{50}+$ eucalyptus leachates $\mathrm{LC}_{50}\left(\mathrm{Cu}-\mathrm{LC}_{50}+\mathrm{EL}^{-} \mathrm{LC}_{50}\right)$. Mixture test solutions were prepared by diluting stock solutions of copper and EL (prepared as described in previous sections) in ASTM hard water, and mixing them. It should be noted that stock-EL has high concentration of DOC (Table 1). Because no standardization of DOC content among mixture test solutions was made, different treatments have distinct DOC contents. This is important because DOC is likely to bind to copper reducing its bioavailability in test media. Therefore, the toxicological interactions assessed in the present study are those expected to occur in real scenarios under simultaneous contamination of water with EL and copper, considering the overall effects on organisms and not those resulting from individual chemicals. The $\mathrm{pH}$ values of test solutions, measured at the beginning of the bioassays are indicated in Table 3, and they were always higher than $7.13 \mathrm{pH}$ units. Bioassays were carried out in conditions similar to those described in sections 'Collection and acclimatization of invertebrates' and 'Bioassays with eucalyptus leachates'. The ranges of d.w. of the tested organisms were: $2.68 \mathrm{mg} \pm 0.010$ at $10^{\circ} \mathrm{C}$ and $2.67 \mathrm{mg} \pm 0.011$ at $20^{\circ} \mathrm{C}$ for $A$. desmarestii, $1.12 \mathrm{mg} \pm 0.003$ at $10^{\circ} \mathrm{C}$ and $1.12 \mathrm{mg} \pm 0.004$ at $20^{\circ} \mathrm{C}$ for E. meridionalis and $0.017 \mathrm{mg} \pm 0.0002$ at $10^{\circ} \mathrm{C}$ and $0.015 \mathrm{mg} \pm 0.0004$ at $20^{\circ} \mathrm{C}$ for S. festiva.

\section{Statistical analysis}

The concentrations inducing $10 \%\left(\mathrm{LC}_{10}\right), 20 \%\left(\mathrm{LC}_{20}\right)$ and $50 \%\left(\mathrm{LC}_{50}\right)$ of mortality were determined from the log concentration versus response (probit transformation of mortality percentages) toxicity curves. To compare the sensitivity of different species at distinct temperatures, a two-way analysis of covariance ( 2 way-ANCOVA) was used. The probit transformed \% of mortality was used as dependent variable; temperature and species as independent variables (fixed factors) and the $\log _{10}$ of the chemical concentration as covariate; when significant differences were found, one-way analysis of covariance (ANCOVA) was used to identify their potential causes, followed by a posteriori LSD tests whenever necessary. In the mixture bioassays, the results are expressed as the concentrations of tannic acid only; the concentrations of copper are not indicated to avoid bias resulting from the potential binding of copper to DOC and thus from the differences between nominal and actual copper concentrations. Binary comparisons of the toxicity curves obtained for each species and temperature in the bioassays with EL alone and in the mixture with copper where compared using ANCOVA. Preliminary check of ANCOVA assumptions was done in all cases. In the mixture bioassays, no mixture models were used to investigate the types of interactions because of the potential bias in the bioavailability of copper due to differences in DOC content in distinct treatments. 
Table 3. Values of $\mathrm{pH}$ (in $\mathrm{pH}$ units) measured at the beginning of the bioassays with eucalyptus leachates (EL) and copper (Cu) mixtures carried out at 10 and $20^{\circ} \mathrm{C}$.

\begin{tabular}{|c|c|c|c|}
\hline \multirow[b]{2}{*}{ Temp. $\left({ }^{\circ} \mathrm{C}\right)$} & \multicolumn{3}{|c|}{ Mixture bioassay } \\
\hline & Treat. & $0 \mathrm{~h}$ & Variat. \\
\hline & \multicolumn{3}{|c|}{ A. desmarestii } \\
\hline \multirow[t]{3}{*}{10} & $\overline{\text { EL-LC }_{10}+\mathrm{CuLC}_{10}}$ & $7.67 \pm 0.00$ & 0.58 \\
\hline & $\mathrm{EL}^{-\mathrm{LC}_{20}}+\mathrm{CuLC} 20$ & $7.32 \pm 0.01$ & 0.28 \\
\hline & $\mathrm{EL}^{-\mathrm{LC}_{50}}+\mathrm{CuLC}_{50}$ & $7.32 \pm 0.01$ & 0.61 \\
\hline \multirow[t]{4}{*}{20} & EL-LC $10+\mathrm{CuLC}_{10}$ & $7.23 \pm 0.01$ & 0.49 \\
\hline & EL-LC $20+\mathrm{CuLC}_{20}$ & $7.22 \pm 0.00$ & 0.82 \\
\hline & $\mathrm{EL}^{-\mathrm{LC}_{50}}+\mathrm{CuLC}_{50}$ & $7.13 \pm 0.01$ & 0.48 \\
\hline & \multicolumn{3}{|c|}{ E. meridionalis } \\
\hline \multirow[t]{3}{*}{10} & ${\mathrm{EL}-\mathrm{LC}_{10}+\mathrm{CuLC}_{10}}$ & $7.66 \pm 0.00$ & 0.59 \\
\hline & $\mathrm{EL}-\mathrm{LC}_{20}+\mathrm{CuLC}_{20}$ & $7.58 \pm 0.01$ & 0.42 \\
\hline & EL-LC $_{50}+\mathrm{CuLC}_{50}$ & $7.33 \pm 0.00$ & 0.38 \\
\hline \multirow[t]{3}{*}{20} & $\mathrm{EL}_{-} \mathrm{LC}_{10}+\mathrm{CuLC}_{10}$ & $7.68 \pm 0.01$ & 0.41 \\
\hline & $\mathrm{EL}^{-\mathrm{LC}_{20}}+\mathrm{CuLC} 20$ & $7.36 \pm 0.00$ & 0.22 \\
\hline & $\mathrm{EL}^{-\mathrm{LC}_{50}}+\mathrm{CuLC}_{50}$ & $7.29 \pm 0.02$ & 0.32 \\
\hline
\end{tabular}

The values indicated are the mean of the $\mathrm{pH}$ values determined in ten replicates per treatment with the corresponding standard errors. Temp., temperature; Treat., treatment; Variat., $\mathrm{pH}$ variation during the assay ( $\mathrm{pH}$ at time $0-\mathrm{pH}$ at $96 \mathrm{~h}$ ). $\mathrm{pH}$ units in control treatment: $7.82 \pm 0.05$; Variat $=0.63$.

\section{Results}

\section{Species sensitivity to single substances and temperature effects}

In all the bioassays carried out with eucalyptus leachates, the mortality in control treatments was $0 \%$, except in the test with E. meridionalis at $20{ }^{\circ} \mathrm{C}$ where $20 \%$ of mortality in the control group was recorded. In each test beaker, the water temperature variation was less than $1{ }^{\circ} \mathrm{C}$, D.O. was always higher than $9.12 \mathrm{mg} . \mathrm{L}^{-1}$; the $\mathrm{pH}$ of test solutions at the beginning of the bioassays was always higher than $3.9 \mathrm{pH}$ units (Appendix 1), the maximal $\mathrm{pH}$ variation during the assays was 0.91 ; and the conductivity variation was always lower than $71 \mu \mathrm{S} . \mathrm{cm}^{-1}$. Mortality recorded is provided in supplementary material (Appendix 2), whereas the $96 \mathrm{~h} \mathrm{LC}_{10}, \mathrm{LC}_{20}$ and $\mathrm{LC}_{50}$ calculated from the toxicity curves (Fig. 1) are indicated in Table 2. For S. festiva, the calculation of $\mathrm{LC}_{x}$ values from the results of the first bioassay was not possible because mortality was only observed at the highest concentration tested. In the second bioassay, the calculation of $\mathrm{LC}_{10}, \mathrm{LC}_{20}$ and $\mathrm{LC}_{50}$ was possible but without confidence limits; also, the estimated $\mathrm{LC}_{50}$ of tannic acid exceeds its concentration in $100 \%$ of eucalyptus leachates. Therefore, due to these constraints, this species was not included in further statistical analysis. The $\mathrm{LC}_{50}$ obtained for $A$. desmarestii and E. meridionalis in single bioassays ranged from 34.346 to $141.577 \mathrm{mg} . \mathrm{L}^{-1}$ of tannic acid (Table 2). The lowest values were obtained at $20^{\circ} \mathrm{C}$ for both species, being about 4.1- and 1.2-folds lower than the corresponding values obtained at $10^{\circ} \mathrm{C}$ for $A$. desmarestii and E. meridionalis, respectively. The comparison of $A$. desmarestii and E. meridionalis toxicity curves (Fig. 1) by 2 wayANCOVA indicated no significant differences between

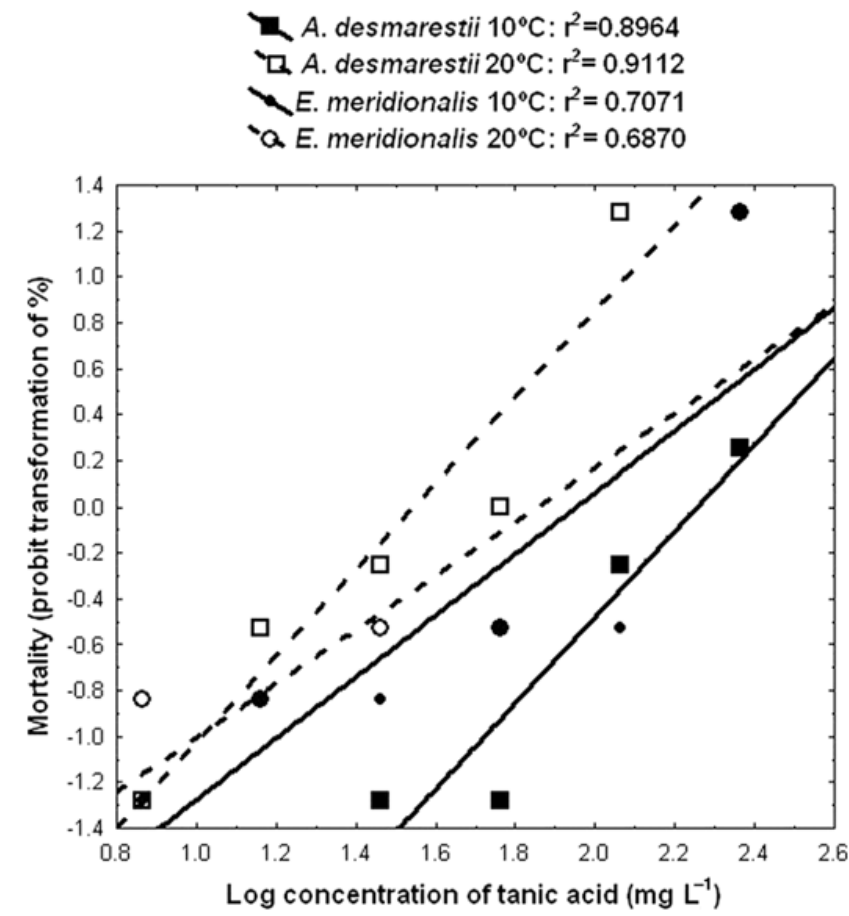

Fig. 1. Acute toxicity of eucalyptus leachates to A. desmarestii and E. meridionalis at 10 and $20^{\circ} \mathrm{C}$. Lines represent linear regression, $R^{2}$ for the two organisms and temperatures are displayed in the graphic.

species $\left(F_{(1,16)}=0.5, \quad P>0.05\right)$; a significant effect of temperature $\left(F_{(1,16)}=10.8, \quad P<0.01\right)$ explaining $40.3 \%$ of total variance, and a significant interaction between species and temperature $\left(F_{(1,16)}=5.9, P<0.05\right)$ explaining $26.9 \%$ of the variance. The increase of temperature from 10 to $20{ }^{\circ} \mathrm{C}$, significantly increased the toxicity of 

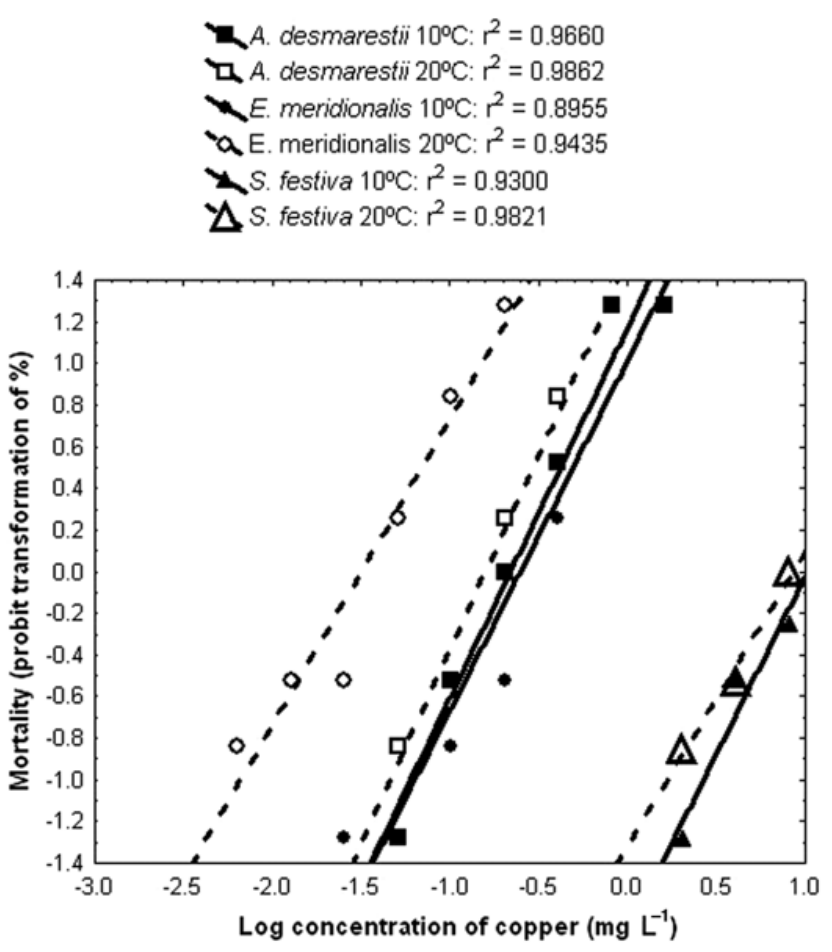

Fig. 2. Acute toxicity of copper to A. desmarestii, E. meridionalis and $S$. festiva at 10 and $20^{\circ} \mathrm{C}$. Lines represent linear regression, $R^{2}$ square for the two organisms and temperatures are displayed in the graphic.

eucalyptus leachates to $A$. desmarestii (ANCOVA: $\left.F_{(1,8)}=36, P<0.01\right)$ but no significant differences between the toxicity curves at 10 and $20{ }^{\circ} \mathrm{C}$ were found for E. meridionalis (ANCOVA: $F_{(1,8)}=0.4, P>0.05$ ).

In all the bioassays carried out with copper, the mortality in control treatments was always equal or lower than $10 \%$, the water temperature variation was $<1{ }^{\circ} \mathrm{C}$; D.O. was always higher than $9.09 \mathrm{mg} . \mathrm{L}^{-1}$; the $\mathrm{pH}$ of test solutions at the beginning of the bioassays was always higher than $7.5 \mathrm{pH}$ units (Appendix 1), the maximal $\mathrm{pH}$ variation during the assays was 0.82 ; and the conductivity variation was always lower than $62 \mu \mathrm{S} . \mathrm{cm}^{-1}$. The mortality recorded in copper bioassays is provided in the supplementary material (Appendix 2), whereas the $\mathrm{LC}_{10}$, $\mathrm{LC}_{20}$ and $\mathrm{LC}_{50}$ are shown in Table 2. The $\mathrm{LC}_{50}$ of copper ranged from 0.036 to $9.0 \mathrm{mg} . \mathrm{L}^{-1}$, with $\mathrm{LC}_{50}$ values being higher at $10{ }^{\circ} \mathrm{C}$ than at $20^{\circ} \mathrm{C}$ (about 1.3 -folds for both S. festiva and A. desmarestii, and 7.4-folds for E. meridionalis, respectively) (Table 2). The comparison of the toxicity curves (Fig. 2) by 2-way ANCOVA, indicated the significant differences among species $\left(F_{(2,22)}=162.1\right.$, $P<0.01)$; significant effects of temperature $\left(F_{(1,22)}=51.2\right.$, $P<0.01)$; and the interaction between species and temperature was also significant $\left(F_{(1,22)}=25.0, P<0.01\right)$. Comparing now the three species at $10^{\circ} \mathrm{C}$, significant differences of sensitivity were found (ANCOVA: $\left.F_{(1,11)}=68.87, P<0.01\right)$ with $S$. festiva being less sensitive (Table 2) than $A$. desmarestii and E. meridionalis (S. festiva versus $A$. desmaresti: $P<0.01 ; \quad S$. festiva versus E. meridionalis: $P<0.01)$, whereas no significant differences of sensitivity between $A$. desmarestii and E. meridionalis were found $(P>0.05)$. At $20{ }^{\circ} \mathrm{C}$, significant differences of sensitivity between $S$. festiva and each of the other species were found ( $S$. festiva versus $A$. desmaresti: $P<0.01 ; S$. festiva versus $E$. meridionalis: $P<0.01$ ), with $S$. festiva being less sensitive that the other two species; significant differences between $A$. desmarestii and E. meridionalis were also registered $(P<0.01)$. Temperature significantly increased the toxicity of copper to $A$. desmarestii and E. meridionalis (ANCOVA: $F_{(1,8)}=6.5, P<0.05$ for $A$. desmarestii and $F_{(1,8)}=53.6$, $P<0.01$ for E. meridionalis) with more pronounced effects in E. meridionalis. No significant differences between temperatures were observed for $S$. festiva (ANCOVA $\left.F_{(1,3)}=4.3, P>0.05\right)$.

\section{Mixture bioassays}

In all the mixtures bioassays, the water temperature variation was less than $1{ }^{\circ} \mathrm{C}$; D.O. was always higher than $9.32 \mathrm{mg} . \mathrm{L}^{-1}$; the $\mathrm{pH}$ of test solutions at the beginning of the bioassays was always higher than $7.13 \mathrm{pH}$ units (Table 3); the maximal $\mathrm{pH}$ variation during the assays was 0.82 ; and the conductivity variation was always lower than $67 \mu \mathrm{S} . \mathrm{cm}^{-1}$. The results of the mixtures bioassays, expressed as percentage of mortality are detailed in the supplementary material (Appendix 2). Because of the low mortality of S. festiva in the eucalyptus leachates solutions, even at the highest exposure concentrations tested, and the lack of relevance of testing eucalyptus leachate concentrations higher than $100 \%$, this species was not included in further statistical analysis of mixture bioassays. The comparison of the mixture toxicity curves based on the concentration of tannic acid (Fig. 3) indicates significant differences between species (2-way ANCOVA: $F_{(1,6)}=92.04, P<0.01$ ), significant differences between temperatures (2-way ANCOVA: $F_{(1,6)}=108.45, P<0.01$ ), and no significant interaction between species and temperature (2-way ANCOVA: $F_{(1,6)}=3.95, P>0.05$ ). The $\mathrm{LC}_{50}$ for the mixture are shown in Table 4, based on the concentrations of tannic acid. Significant differences between the toxicity curves of EL alone and of the mixture with copper were found for E. meridionalis at $20^{\circ} \mathrm{C}$ (ANCOVA: $\left.F_{(1,6)}=25.10, P<0.01\right)$, whereas at $10^{\circ} \mathrm{C}$ no significant differences were found (ANCOVA: $F_{(1,6)}=2.49, P>0.05$ ). For $A$. desmarestii at both temperatures no significant differences between the toxicity curves of EL alone and of the mixture were found (ANCOVA: $F_{(1,3)}=1.12, P>0.05$ and $F_{(1,5)}=3.76, P>0.05$, for 10 and $20^{\circ} \mathrm{C}$, respectively).

\section{Discussion}

\section{Bioassays with single substances and temperature effects}

In the bioassays with EL, no correction of $\mathrm{pH}$ or DOC concentration were made to simulate the overall processes 


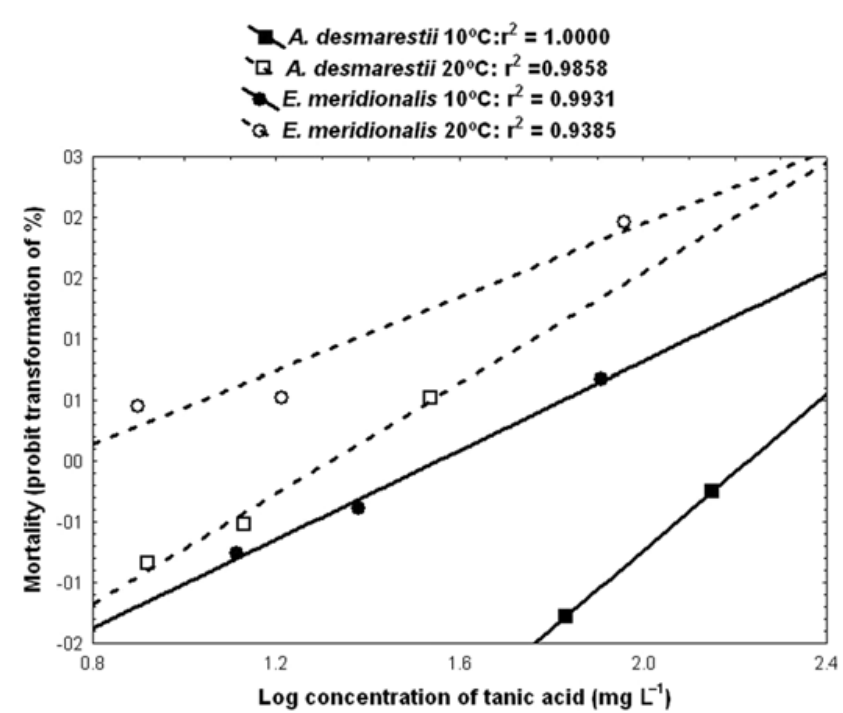

Fig. 3. Acute combined toxicity of eucalyptus leachates to A. desmarestii and E. meridionalis at 10 and $20^{\circ} \mathrm{C}$. Lines represent linear regression, $R^{2}$ for the two organisms and temperatures are displayed in the graphic.

likely occurring in real scenarios. Thus, the toxic effects assessed include those induced by eucalyptus leaf toxins and $\mathrm{pH}$ effects under different DOC concentrations. This is important because low $\mathrm{pH}$ values such as those found in the two highest EL treatments (Appendix 1) may have adverse effects on the organisms per se (Felten and Guérold, 2006; Janssens de Bisthoven et al., 2006), and distinct species may have different sensitivities to both eucalyptus leaf toxins and $\mathrm{pH}$ variation.

The low mortality of $S$. festiva in the bioassays with single substances and the lack of significant influence of temperature on the toxicity of the chemicals tested indicate that this species was less sensitive to chemical/pH stress and temperature changes than $A$. desmarestii and E. meridionalis. S. festiva has a case and the test period was relatively short $(96 \mathrm{~h})$; in these conditions, the starvation pressure may have not been high enough to force the organisms to go out of the case in order to search for food. That behaviour probably allowed the larvae to avoid (or reduce) the exposure to environmental contaminants and low $\mathrm{pH}$ values, as suggested by the low mortality recorded in the two highest EL treatments with $\mathrm{pH}$ values of 3.9 and 4.5 (supplementary material); this could also explain, at least in part, the lack of influence of temperature on chemicals' toxicity in this species. The finding that this species was the least sensitive to both EL and copper-induced stress may also suggest the presence of general mechanisms decreasing the uptake of environmental contaminants, increasing their elimination, and/or an efficient ionic regulation. In fact, mechanisms of tolerance to metals (Darlington and Gower, 1990) and differential patterns of metal accumulation were reported for other Trichopteran larvae (Cain and Luoma, 1998; Rainbow, 2002, 2007; Rainbow et al., 2012). Furthermore, the lower sensitivity of $S$. festiva to chemical and/or $\mathrm{pH}$ stress relatively to other shredder species found in the
Table 4. Acute combined (96 h) toxicity of eucalyptus leachates and copper for Atyaephyra desmarestii, and Echinogammarus meridionalis at 10 and $20{ }^{\circ} \mathrm{C}$. $\mathrm{LC}_{50^{-}} 50 \%$ lethal concentrations calculated from the toxicity curves (log concentrations versus probit transformation of mortality $\%$ )

\begin{tabular}{llll}
\hline Temp. $\left({ }^{\circ} \mathrm{C}\right)$ & \multicolumn{1}{c}{ Species } & \multicolumn{2}{c}{$\mathrm{LC}_{50}\left(\mathrm{mg} . \mathrm{L}^{-1}\right)$} \\
\hline \multirow{2}{*}{20} & A. desmarestii & $160.869 \mathrm{EL}$ & $(111.564-3782.292)$ \\
& E. meridionalis & $35.898 \mathrm{EL}$ & $(26.409-52.589)$ \\
& A. desmarestii & $20.874 \mathrm{EL}$ & $(12.055-114.242)$ \\
& E. meridionalis & $4.972 \mathrm{EL}$ & (n.a.) \\
\hline
\end{tabular}

EL, eucalyptus leachates concentrations expressed in $\mathrm{mg}$ of tannic acid. $L^{-1} .95 \%$ confidence limits for the estimates are given within brackets.

present study, is in good agreement with previous findings in the caddisfly Sericostoma vittatum exposed to aerated eucalyptus leachates (Canhoto and Laranjeira, 2007; Canhoto et al., 2013).

In the present study, no significant differences of sensitivity to copper-induced stress between $A$. desmarestii and E. meridionalis were found at $10^{\circ} \mathrm{C}$ (Fig. 2, Table 2). The main mechanism of acute copper toxicity in aquatic organisms is the disruption of ionoregulatory processes, particularly through its influence on $\mathrm{Na}^{+}$transport mechanisms, with effects on the internal concentrations and transport of several other ions (Santore et al., 2001; Grosell et al., 2002, Paquin et al., 2002). Thus, our study suggests a similar action of copper on these mechanisms in both $A$. desmarestii and E. meridionalis at $10^{\circ} \mathrm{C}$. Additionally, copper is a well-known oxidative stress inducer in both vertebrates (e.g. Olivari et al., 2008; Roy et al., 2009; Vieira et al., 2009; Boveris et al., 2012) and invertebrates (Maria and Bebianno, 2011; Gomes et al., 2012), including shredders (Bouskill et al., 2006; Sroda and Cossu-Leguille, 2011). Thus, damage in crucial molecules (e.g. proteins, lipids and DNA) as a result of oxidative stress, may also have contributed to its toxic effects. If so, the findings of the present study, suggest an overall similar effect in both species at $10^{\circ} \mathrm{C}$. The raise of temperature from 10 to $20^{\circ} \mathrm{C}$ increased the toxicity of copper to both species, with more pronounced effects in E. meridionalis (Fig. 2, Table 2). Ionoregulatory processes in ectotherms are temperature dependent, in general with higher turnovers at higher temperatures (Huang et al., 2009; Tattersall et al., 2012). Thus, the increase of copper toxicity at $20^{\circ} \mathrm{C}$ relatively to $10^{\circ} \mathrm{C}$ may be due to an increased ion turnover at the highest temperature. Also, the raise of temperature in general increases the production of reactive oxygen species (Abele et al., 1998, 2002; Heise et al., 2003) potentially increasing oxidative stress effects and damage. Therefore, the differential effect of temperature on the copper toxicity to E. meridionalis and $A$. desmarestii suggests that ion turnover and/or oxidative stress targets and defenses are affected by temperature in a different way in the two species. This is a most interesting topic deserving further investigation.

Previous studies indicate that $A$. desmarestii may show a $\mathrm{pH}$-tolerance $(\mathrm{pH}>5)$ when facing short-term exposure to acidified water at temperatures about $18^{\circ} \mathrm{C}$ (Janssens 
de Bisthoven et al., 2006). Nonetheless with $\mathrm{pH}$ values between 3.3 and 4.4 (similar to the ones found in our study for the highest EL treatments) mortality increased and behavioural alterations were also detected and this negative effect may have been amplified by increasing temperature. Amphipods have been referred as extremely sensitive to low $\mathrm{pH}$ with effects on osmoregulation processes: Felten et al. (2006, 2008) and Felten and Guérold (2006) detected a depletion of haemolymph $\mathrm{Na}^{+}$and $\mathrm{Cl}^{-}$in Gammarus fossarum when exposed to acidic conditions with observed increased mortality. The lack of significant differences on EL toxicity between $A$. desmarestii and $E$. meridionalis at $10{ }^{\circ} \mathrm{C}$ (Fig. 1, Table 2) suggests a comparable sensitivity to eucalyptus leaf toxins and/or low $\mathrm{pH}$ values at this temperature. This similar low $\mathrm{pH}$-induced stress in the highest EL treatments suggests a comparable ability of regulating $\mathrm{H}^{+}$ions thus supporting the hypothesis raised above on the similarity of ionoregulatory processes between the two species. However, the raise of temperature increased the toxicity of EL to $A$. desmarestii but not to $E$. meridionalis suggesting that other mechanisms are involved in the toxicity and or biotransformation of EL, which are modulated by high temperatures in a distinct way in the two species. Unfortunately, our experimental design does not allow going further on the mechanisms potentially involved.

\section{Mixture bioassays}

In the mixture bioassays with EL and copper, low $\mathrm{pH}$ and DOC may act as important confounding factors: $\mathrm{pH}$ variation may change the speciation of copper with implications for its toxicity, and low $\mathrm{pH}$ causes toxicity per se (Felten and Guérold, 2006; Janssens de Bisthoven et al., 2006); DOC binds copper molecules decreasing its bioavailability (De Schamphelaere and Janssen, 2004). In our experimental conditions, the $\mathrm{pH}$ of all test solutions was similar (Table 3 ) and the maximal $\mathrm{pH}$ variation in test beakers was 0.82 . Thus, no significant stress due to low $\mathrm{pH}$ values or $\mathrm{pH}$ variation occurred. To mimic processes likely happening in real stream scenarios, the DOC concentrations were not standardized across treatments, resulting in a different DOC content in different EL treatments. Therefore, the overall effects of EL and copper in mixture are likely those occurring in real scenarios, where DOC concentrations may change with implications for copper bioavailability and toxicity. The $\mathrm{LC}_{50}$ values of the mixture bioassays (Table 4) are expressed in concentrations of tannic acid because the concentrations of bioavailable copper in test solutions may be different from the nominal concentrations due to binding to DOC. $\mathrm{LC}_{50}$ values for $A$. desmarestii were higher than the ones obtained for E. meridionalis, which can indicate a low sensitivity of this species to EL in the presence of copper. Additionally, the $\mathrm{LC}_{50}$ obtained for the mixture at $10^{\circ} \mathrm{C}$ was higher than the one previously obtained in single exposures (Tables 2 and 4). Because copper is a wellknown oxidative stress inducer (Bouskill et al., 2006;
Sroda and Cossu-Leguille, 2011) and eucalyptus components present in oils and extracts have anti-oxidant properties (Sacchetti et al., 2005; Singh et al., 2012), this may contribute, at least in part, for the higher $\mathrm{LC}_{50}$ of the mixture relatively to $\mathrm{LC}_{50}$ of the chemicals alone in $A$. desmarestii (Tables 2 and 4). Interestingly, in E. meridionalis the toxicity of the mixture was higher than the toxicities induced by EL and copper individually, especially at $20^{\circ} \mathrm{C}$ (Tables 2 and 4, Figs. 1-3). Thus, these results also suggest a distinct effect of temperature raise between $A$. desmarestii and E. meridionalis.

Stressors' exposure may be a most important pressure driving the composition and dynamics of shredders communities, mainly because different species may have distinct sensitivities to them (Liess and Schulz, 1999; Woodcock and Huryn, 2005; Maltby and Hills, 2008). Thus, under stress exposure, the populations of the most sensitive species are expected to decline and even disappear, whereas the most tolerant ones may overdevelop due to the lack of competition, possibly occupying the ecological niches of the extinct ones.

\section{Conclusions}

In summary, the results of this study indicated differences of sensitivity to the stress induced by copper, eucalyptus leaf leachates (EL) and their mixtures among S. festiva, A. desmarestii and E. meridionalis. S. festiva was the least sensitive species at both 10 and $20^{\circ} \mathrm{C}$. The relative sensitivity of $A$. desmarestii and $E$. meridionalis was dependent of the chemicals tested, and of the environmental temperature. Overall, the findings of the present study suggest that single and combined chemical stress induced by copper and EL, when present alone or in mixture in stream's water, is able to modulate the biodiversity of stream shredders communities due to differential sensitivity of individual species to environmental contaminants, and that temperature influences the process. Therefore, more knowledge on the effects of multi-stressors effects on shredder communities is needed.

Acknowledgements. The authors would like to thank Professor Denise Mendonça for advises on statistical analysis. This study was partially financed by the European Fund for Economic and Regional Development (FEDER) through the Programme Operational Factors of Competitiveness (COMPETE) and National Funds through the Portuguese Foundation of Science and Technology (PTDC/CLI/67180/2006; FCOMP-01-0124FEDER-007112; PEST-C/MAR/LA0015/2013). This work was supported by the Portuguese Science and Technology Foundation (FCT) through a $\mathrm{PhD}$ grant to Mafalda Gama (SFRH/BD/47033/2008).

\section{References}

Abele D., Burlando B., Viarengo A. and Pfrtner H.O., 1998. Exposure to elevated temperatures and hydrogen peroxide 
elicits oxidative stress and antioxidant response in the Antarctic intertidal limpet Nacella concinna. Comp. Biochem. Physiol. B, 120, 425-435.

Abele D., Heise K., Pfrtner H.O. and Puntarulo S., 2002. Temperature dependence of mitochondrial function and production of reactive oxygen species in the intertidal mud clam Mya arenaria. J. Exp. Biol., 205, 1831-1841.

Allan J.D. and Castillo M.M., 2007. Stream Ecology (2nd edn,), Springer, Dordrecht, The Netherlands, $436 \mathrm{p}$.

ASTM - American Society for Testing and Materials., 1980. Standard practice for conducting acute toxicity tests with fishes, macroinvertebrates and amphibians. Report E 790-80. American Society for Testing and Materials, Philadelphia.

Batista D., Pascoal C. and Cássio F., 2012. Impacts of warming on aquatic decomposers along a gradient of cadmium stress. Environ. Pollut., 169, 35-41.

Boeckman C.J. and Bidwell J.R., 2006. The effects of temperature, suspended solids, and organic carbon on copper toxicity to two aquatic invertebrates. Water Air Soil Pollut., 171, 185-202.

Bouskill N.J., Handy R.D., Ford T.E. and Galloway T.S., 2006. Differentiating copper and arsenic toxicity using biochemical biomarkers in Asellus aquaticus and Dreissena polymorpha. Ecotox. Environ. Safe., 65, 342-349.

Boveris A., Musacco-Sebio R., Ferrarotti N., Saporito-Magriná C., Torti H., Massot F. and Repetto M.G., 2012. The acute toxicity of iron and copper: biomolecule oxidation and oxidative damage in rat liver. J. Inorg. Biochem., 116, 63-69.

Brix K.V., DeForest D.K. and Adams W.J., 2011. The sensitivity of aquatic insects to divalent metals: a comparative analysis of laboratory and field data. Sci. Total Environ., 409, 4187-4197.

Cain D.J. and Luoma S.N., 1998. Metal exposures to native populations of caddisfly Hydropsyche (Trichoptera: Hydropsychedae) determined from cytosolic and whole body metal concentrations. Hydrobiologia, 386, 103-117.

Canhoto C. and Graça M.A.S., 1999. Leaf barriers to fungal colonization and shredders (Tipula lateralis) consumption of decomposing Eucalyptus globulus. Microb. Ecol., 37, $163-172$.

Canhoto C. and Laranjeira C., 2007. Leachates of Eucalyptus globulus in intermittent streams affect water parameters and invertebrates. Int. Rev. Hydrobiol., 92(2), 173-182.

Canhoto C., Calapez R., Gonçalves A.L. and Moreira-Santos M., 2013. Effects of Eucalyptus leachates and oxygen on leaflitter processing by fungi and stream invertebrates. Freshwat. Sci., 32(2), 411-424.

Chatzinikolaou Y., Dakos V. and Lazaridou M., 2006. Longitudinal impacts of anthropogenic pressures on benthic macroinvertebrate assemblages in a large transboundary Mediterranean river during the low flow period. Acta Hydrochim. Hydrobiol., 34, 453-463.

Cummins K.W., 1973. Trophic relations of aquatic insects. Annu. Rev. Entomol., 18, 183-206.

Darlington S.T. and Gower A.M., 1990. Location of copper in larvae of Plectrocnemia conspersa (Curtis) (Trichoptera) exposed to elevated metal concentrations in a mine drainage stream. Hydrobiologia, 196, 91-100.

Dédourge-Geffard O., Palais F., Biagianti-Risbourg S., Geffard O. and Geffard A., 2009. Effects of metals on feeding rate and digestive enzymes in Gammarus fossarum: an in situ experiment. Chemosphere, 77, 1569-1576.

De Schamphelaere K.A.C. and Janssen C.R., 2004. Development and field validation of a biotic ligand model predicting chronic copper toxicity to Daphnia magna. Environ. Toxicol. Chem., 23, 1365-1375.

Dudgeon D., Arthington A.H., Gessner M.O., Kawabata Z., Knowler D.J., Lévêque C., Naiman R.J., Prieur-Richard A., Soto D., Stiassny M.L.J. and Sullivan C.A., 2006. Freshwater biodiversity: importance, threats, status and conservation challenges. Biol. Ver., 81, 163-182.

Farag A.M., Woodward D.F., Goldstein J.N., Brumbaugh W. and Meyer J.S., 1998. Concentrations of metals associated with mining waste in sediments, biofilm, benthic macroinvertebrates, and fish from the Coeur d'Alene river basin, Idaho. Arch. Environ. Contam. Toxicol., 34, 119-127.

Faria M.S., Lopes R.J., Nogueira A.J.A. and Soares A.M.V.M., 2007. In situ and laboratory bioassays with Chironomus riparius larvae to assess toxicity of metal contamination in rivers: the relative toxic effect of sediment versus water contamination. Environ. Toxicol. Chem., 26, 1968-1977.

Faria M.S., Lopes R.J., Malcato J., Nogueira A.J.A. and Soares A.M.V.M., 2008. In situ bioassays with Chironomus riparius larvae to biomonitor metal pollution in rivers and to evaluate the efficiency of restoration measures in mine areas. Environ. Pollut., 151, 213-221.

Felten V. and Guérold F., 2006. Short-term physiological responses to a severe acid stress in three macroinvertebrate species: a comparative study. Chemosphere, 63, 1427-1435.

Felten V., Baudoin J.M. and Guérold F., 2006. Physiological recovery from episodic acid stress does not mean population recovery of Gammarus fossarum. Chemosphere, 65, 988-998.

Felten V., Charmantier G., Charmantier-Daures M., Aujoulat F., Garric J. and Geffard O., 2008. Physiological and behavioural responses of Gammarus pulex exposed to acid stress. Comp. Biochem. Physiol C, 147, 189-197.

Ferreira V., Gonçalves A.L., Godbold D.W. and Canhoto C., 2010. Effect of increased atmospheric $\mathrm{CO}_{2}$ on the performance of an aquatic detritivore through changes in water temperature and litter quality. Glob. Change Biol., 16, 3284-3296.

Forrow D.M. and Maltby L., 2000. Toward a mechanistic understanding of contaminant-induced changes in detritus processing in streams: direct and indirect effects on detritivore feeding. Environ. Toxicol. Chem., 19(8), 21002106.

Gerhardt A., Janssens de Bisthoven L. and Soares A.M.V.M., 2004. Macroinvertebrate response to acid mine drainage: community metrics and on-line behavioural toxicity bioassay. Environ. Pollut., 130, 263-274.

Gessner M.O., Swan C.M., Dang C.K., McKie B.G., Bardgett R.D., Wall D.H. and Hättenschwiler S., 2010. Diversity meets decomposition. Trends Ecol. Evol., 25, 372-380.

Gomes S.I.L., Novais S.C., Gravato C., Guilhermino L., ScottFordsmand J.J., Soares A.M.V.M. and Amorim M.J.B., 2012. Effect of $\mathrm{Cu}$-nanoparticles versus one $\mathrm{Cu}$-salt: analysis of stress biomarkers response in Enchytraeus albidus (Oligochaeta). Nanotoxicology, 6(2), 134-143.

Graça M.A.S., Pozo J., Canhoto C. and Elosegi A., 2002. Effects of Eucalyptus plantations on detritus, decomposers, and detritivores in streams. Sci. World, 2, 1173-1185. 
Graça M.A.S., Bärlocher S.F. and Gessner M.O., 2005. Methods to Study Litter Decomposition: A Practical Guide, Springer, The Netherlands, 329 p.

Grosell M., Nielsen C. and Bianchini A., 2002. Sodium turnover rate determines sensitivity to acute copper and silver exposure in freshwater animals. Comp. Biochem. Physiol. C, 133, 287-303.

Heise K., Puntarulo S., Pfrtner H.O. and Abele D., 2003. Production of reactive oxygen species by isolated mitochondria of the Antarctic bivalve Laternula elliptica (King and Broderip) under heat stress. Comp. Biochem. Physiol. C, 134, 79-90.

Hogsden K.L. and Harding J.S., 2012. Consequences of acid mine drainage for the structure and function of benthic stream communities: a review. Freshwat. Sci., 31, 108-120.

Huang F., Rabson D. and Chen W., 2009. Distribution of the $\mathrm{Na} / \mathrm{K}$ Pumps' turnover rates as a function of membrane potential, temperature, and ion concentration gradients and effect of fluctuations. J. Phys. Chem. B., 113, 8096-8102.

IPCC, 2007. Contribution of Working Groups I, II and III to the Fourth Assessment Report of the Intergovernmental Panel on Climate Change. In: Pachauri R.K. and Reisinger A. (eds.), Core Writing Team, IPCC, Geneva, Switzerland, $104 \mathrm{p}$.

Janssens de Bisthoven L., Gerhardt A., Guhr K. and Soares A.M.V.M., 2006. Behavioral changes and acute toxiciy to the freshwater shrimp Atyaephyra desmarestii Millet (Decapoda: Natantia) from exposure to acid mine drainage. Ecotoxicology, 15, 215-227.

Kominoski J.S., Follstad Shah J.J., Canhoto C., Fischer D.G., Giling D.P., González E., Griffiths N.A., Larrañaga A., LeRoy C.J., Mineau M.M., McElarney Y.R., Shirley S.M., Swan C.M., and Tiegs S.D., 2013. Forecasting functional implications of global changes in riparian plant communities. Front. Ecol. Environ., 11, 423-432.

Lapointe D., Pierron F. and Couture P., 2011. Individual and combined effects of heat stress and aqueous or dietary copper exposure in fathead minnows (Pimephales promelas). Aquat. Toxicol., 104, 80-85.

Larrañaga A., Basarugen A. and Pozo J., 2009. Impacts of Eucalyptus globulus plantations on physiology and population densities of invertebrates inhabiting Iberian Atlantic streams. Int. Rev. Hydrobiol., 94(4), 497-511.

Lecerf A. and Richardson J.S., 2010. Litter decomposition can detect effects of high and moderate levels of forest disturbance on stream condition. Forest Ecol. Manage., 259, 2433-2443.

Leslie H.A., Pavluk T.I., Bij de Vaate A. and Kraak M.H.S., 1999. Triad assessment of the impact of chromium contamination on benthic macroinvertebrates in the Chusovaya River (Urals, Russia). Arch. Environ. Contam. Toxicol., 37, 182-189.

Liess M. and Beketov M., 2011. Traits and stress: keys to identify community effects of low levels of toxicants in test systems. Ecotoxicology, 20, 1328-1340.

Liess M. and Schulz R., 1999. Linking insecticide contamination and population response in an agricultural stream. Environ. Toxicol. Chem., 18(9), 1948-1955.

Macedo-Sousa J.A., Pestana J.L.T., Gerhardt A., Nogueira A.J.A. and Soares A.M.V.M., 2007. Behavioural and feeding responses of Echinogammarus meridionalis (Crustacea,
Amphipoda) to acid mine drainage. Chemosphere, 67, 1663-1670.

Macedo-Sousa J. A., Gerhardt A., Brett C.M.A., Nogueira A.J.A. and Soares A.M.V.M., 2008. Behavioural responses of indigenous benthic invertebrates (Echinogammarus meridionalis, Hydropsyche pellucidula and Choroterpes picteti) to a pulse of Acid Mine Drainage: a laboratorial study. Environ. Pollut., 156, 966-973.

Malmqvist B. and Rundle S., 2002. Threats to the running water ecosystems of the world. Environ. Conserv., 29, 134-153.

Maltby L. and Hills L., 2008. Spray drift of pesticides and stream macroinvertebrates: experimental evidence of impacts and effectiveness of mitigation measures. Environ. Pollut., 156, $1112-1120$.

Maria V.L. and Bebianno M.J., 2011. Antioxidant and lipid peroxidation responses in Mytilus galloprovincialis exposed to mixtures of benzo(a)pyrene and copper. Comp. Biochem. Physiol. C, 154, 56-63.

McFeeters B.J. and Frost P.C., 2011. Temperature and the effects of elemental food quality on Daphnia. Freshwat. Biol., $56,1447-1455$.

McMahon T.A., Halstead N.T., Johnson S., Raffel T.R., Romansic J.M., Crumrine P.W. and Rohr J.R., 2012. Fungicide-induced declines of freshwater biodiversity modify ecosystem functions and services. Ecol. Lett., 15, 714-722.

Molinero J. and Pozo J., 2004. Impact of a eucalyptus (Eucalyptus globulus Labill.) plantation on the nutrient content and dynamics of coarse particulate organic matter (CPOM) in a small stream. Hydrobiologia, 528, $143-165$.

Morrill J.C., Bales R.C. and Conklin M.H., 2005. Estimating stream temperature from air temperature: implications for future water quality. J. Environ. Eng., 131(1), 139-146.

Olivari F.A., Hernández P.P. and Allende M.L., 2008. Acute copper exposure induces oxidative stress and cell death in lateral line hair cells of zebrafish larvae. Brain Res., 124, $1-12$.

Ormerod S. J., Dobson M., Hildrew A.G. and Townsend C.R., 2010. Multiple stressors in freshwater ecosystems. Freshwat. Bio., 55(1), 1-4.

Pantani C., Pannunzio G., DeCristofaro M., Novelli A.A. and Salvatori M., 1997. Comparative acute toxicity of some pesticides, metals, and surfactants to Gammarus italicus Goedm and Echinogammarus tibaldii Pink, and stock (Crustacea: Amphipoda). Bull. Environ. Contam. Toxicol., 59, 963-967.

Paquin P.R., Gorsuch J.W., Apte S., Batley G.E., Bowles K.C., Campbell P.G.C., Delos C.G., Di Toro D.M., Dwyer R.L., Galvez F., Gensemer R.W., Goss G.G., Hogstrand C., Janssen C.R., McGreer J.C., Naddy R.B., Playle R.C., Santore R.C., Schneider U., Stubblefield W.A., Wood C.M., Wu K.B., 2002. The biotic ligand model: a historical overview. Comp. Biochem. Physiol. C, 133, 3-35.

Perkins D.M., Reiss J., Yvon-Durocher G. and Woodward G., 2010. Global change and food webs in running waters. Hydrobiologia, 657, 181-198.

Pestana J.L.T., Ré A., Nogueira A.J.A. and Soares A.M.V.M., 2007. Effects of cadmium and zinc on the feeding behavior of two freshwater crustaceans: Atyaephyra desmarestii (Decapoda) and Echinogammarus meridionalis (Amphipoda). Chemosphere, 68, 1556-1562. 
Peters A., Crane P. and Adams W.J., 2011. Effects of iron on Benthic Macroinvertebrate Communities in the field. Bull. Environ. Contam. Toxicol., 86, 591-595.

Pradhan, A., Seena, S., Pascoal, C. and Cássio F., 2012. Copper oxide nanoparticles can induce toxicity to the freshwater shredder Allogamus ligonifer. Chemosphere, 89, 1142-1150.

Prato E., Biandolino F. and Scardicchio C., 2009. Effects of temperature on the sensitivity of Gammarus aequicauda (Martynov, 1931) to cadmium. Bull. Environ. Contam. Toxicol., 83, 469-473.

Rainbow P.S., 2002. Trace metal concentrations in aquatic invertebrates: why and so what? Environ. Pollut., 120, 497-507.

Rainbow P.S., 2007. Trace metal bioaccumulation: models, metabolic availability and toxicity. Environ. Int., 33, 576-582.

Rainbow P.S., Hildrew A.G., Smith B.D., Geatches T. and Luoma S. N., 2012. Caddisflies as biomonitors identifying thresholds of toxic metal bioavailability that affect the stream benthos. Environ. Pollut., 166, 196-207.

Richardson J.S. and Danehy R.J., 2007. A synthesis of the ecology of headwater streams and their riparian zones in temperate forests. Forest Sci., 53, 131-147.

Roy D.N., Mandal S., Sen G. and Biswas T., 2009. Superoxide anion mediated mitochondrial dysfunction leads to hepatocyte apoptosis preferentially in the periportal region during copper toxicity in rats. Chem. Biol. Interact., 182, 136-147.

Sacchetti G., Maietti S., Muzzoli M., Scaglianti M., Manfredini S., Radice M. and Bruni R., 2005. Comparative evaluation of 11 essential oils of different origin as functional antioxidants, antiradicals and antimicrobials in foods. Food Chem., 91, 621-632.

Sanpéra-Calbet I., Lecerf A. and Chauvet E., 2009. Leaf diversity influences in-stream litter decomposition through effects on shredders. Freshwat. Bio., 54, 1671-1682.

Santore R.C., Di Toro D.M., Paquin P.R., Allen H.E. and Meyer J.S., 2001. Biotic ligand model of the acute toxicity of metals. 2. Application to acute copper toxicity in freshwater fish and daphnia. Environ. Toxicol. Chem., 20(10), $2397-$ 2402.

Santos R.L., 1997. The Eucalyptus of California: Seeds of Good or Seeds of Evil, Alley-Cass Publications, Denair, CA.

Singh H.P., Kaur S., Negi K., Kumari S., Saini V., Batish D.R. and Kohli R.K., 2012. Assessment of in vitro antioxidant activity of essential oil of Eucalyptus citriodora (lemonscented Eucalypt; Myrtaceae) and its major constituents. Food Sci. Technol., 48, 237-241.

Sroda S. and Cossu-Leguille C., 2011. Effects of sublethal copper exposure on two gammarid species: which is the best competitor? Ecotoxicology, 20, 264-273.

Tattersall G.J., Sinclair B.J., Withers P.C., Fields P.A., Seebacher F., Cooper C.E. and Maloney S. K., 2012. Coping with thermal challenges: physiological adaptations to environmental temperatures. Compr. Physiol., 2, 2151-2202.

Vannote R.L., Minshall G.W., Cummins K.W., Sedell J.R. and Cushing C.E., 1980. The river continuum concept. Can. J. Fish. Aquat. Sci., 37, 130-137.

Vieira L.R. and Guilhermino L., 2012. Multiple stress effects on marine planktonic organisms: influence of temperature on the toxicity of polycyclic aromatic hydrocarbons to Tetraselmis chuii. J. Sea Res., 72, 94-98.

Vieira L.R., Gravato C., Soares A.M.V.M., Morgado F. and Guilhermino L., 2009. Acute effects of copper and mercury on the estuarine fish Pomatoschistus microps: linking biomarkers to behavior. Chemosphere, 76, 1416-1427.

Wojewodzic M.W., Rachamim T. and Hessen D.O., 2011. Effect of temperature and dietary elemental composition on RNA/ protein ratio in a rotifer. Funct. Ecol., 25, 1154-1160.

Woodcock T.S. and Huryn A.D., 2005. Leaf litter processing and invertebrate assemblages along a pollution gradient in a Maine (USA) headwater stream. Environ. Pollut., 134, 363-375.

Woodward G., Perkins D.M. and Brown L.E., 2010. Climate change and freshwater ecosystems: impacts across multiple levels of organization. Phil. Trans. R. Soc. Lond. B Biol. Sci., $365,2093-210$. 